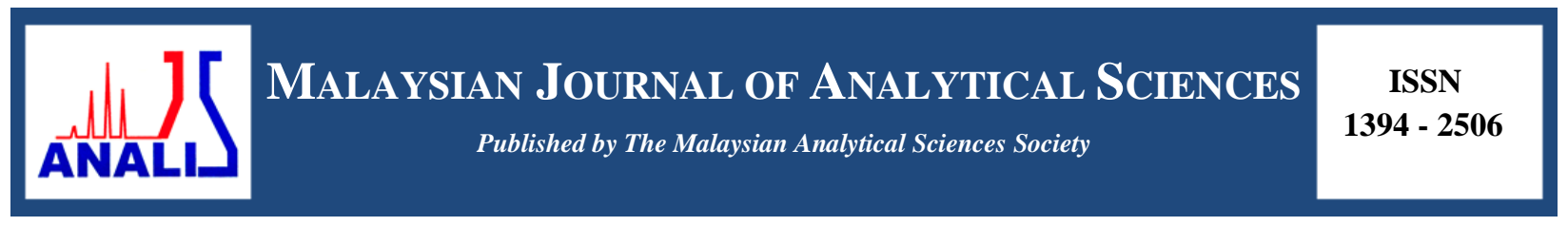

\title{
NUTRIENT DISTRIBUTION IN THE BESUT RIVER BASIN, TERENGGANU, MALAYSIA (SOUTH CHINA SEA)
}

\author{
(Taburan Nutrien di Lembangan Sungai Besut, Terengganu, Malaysia (Laut China Selatan)) \\ Suhaimi Suratman ${ }^{1,2 *}$, Azyyati Abdul Aziz ${ }^{1}$, Tan Hock Seng ${ }^{1}$, Hee Yet Yin ${ }^{1}$, Fatin Adlina Md Nasir ${ }^{1}$, \\ Dung Quang Le ${ }^{3}$, Norhayati Mohd Tahir ${ }^{1}$ \\ ${ }^{1}$ Institute of Oceanography and Environment \\ ${ }^{2}$ Institute of Tropical Biodiversity and Sustainable Development \\ Universiti Malaysia Terengganu, 21030 Kuala Nerus, Terengganu, Malaysia \\ ${ }^{3}$ PETRONAS Twin Towers, \\ Kuala Lumpur City Centre, 50088 Kuala Lumpur, Malaysia \\ *Corresponding author: miman@umt.edu.my
}

Received: 19 August 2018; Accepted: 11 May 2019

\begin{abstract}
The aim of this study was to determine the distribution of nitrogen $(\mathrm{N})$ - and phosphorus (P)-based nutrients in the Besut River basin, Malaysia (South China Sea). The mean concentrations of ammonia, nitrate, total dissolved $\mathrm{N}$ and total particulate $\mathrm{N}$ were $43 \mu \mathrm{g} / \mathrm{L} \mathrm{N}, 195 \mu \mathrm{g} / \mathrm{L} \mathrm{N}, 485 \mu \mathrm{g} / \mathrm{L} \mathrm{N}, 431 \mu \mathrm{g} / \mathrm{L} \mathrm{N}$, respectively. In contrast to N, lower mean concentrations of $\mathrm{P}$ were recorded with values of $2.30 \mu \mathrm{g} / \mathrm{L} \mathrm{P}$ (dissolved inorganic P), $4.84 \mu \mathrm{g} / \mathrm{L} \mathrm{P}$ (total dissolved P) and $8.35 \mu \mathrm{g} / \mathrm{L} \mathrm{P}$ (total particulate P). In general, higher concentrations of nutrients were recorded in the middle and lower reaches of the river basin due to human activities. Elevated levels of both forms of nutrients were present during the wet season due to terrestrial run-off to the water column. The molar ratio of dissolved inorganic N:P (nitrate + ammonia: inorganic P) was extremely high (72:1), much higher than the Redfield ratio (16:1), suggesting the nutrient-limiting factor for phytoplankton growth in this river basin was $\mathrm{P}$. The results from this study can be used as a baseline comparison for future monitoring of this river basin.
\end{abstract}

Keywords: surface water, nutrients, N:P ratio, Besut River basin

\begin{abstract}
Abstrak
Tujuan kajian ini adalah untuk menentukan taburan nutrien berasaskan nitrogen (N) dan fosforus (P) di lembangan Sungai Besut, Malaysia (Laut China Selatan). Purata kepekatan ammonia, nitrat, jumlah N terlarut dan jumlah N partikulat masing-masing adalah $43 \mu \mathrm{g} / \mathrm{L} \mathrm{N}, 195 \mu \mathrm{g} / \mathrm{L} \mathrm{N}, 485 \mu \mathrm{g} / \mathrm{L} \mathrm{N}, 431 \mu \mathrm{g} / \mathrm{L} \mathrm{N}$. Jika dibandingkan dengan N, purata kepekatan P yang direkodkan adalah rendah dengan nilai $2.30 \mu \mathrm{g} / \mathrm{L} \mathrm{P}$ (tak organik $\mathrm{P}$ terlarut), $4.84 \mu \mathrm{g} / \mathrm{L} \mathrm{P}$ (jumlah terlarut $\mathrm{P}$ ) and $8.35 \mu \mathrm{g} / \mathrm{L} \mathrm{P}$ (jumlah partikulat P). Umumnya, kepekatan nutrien adalah tinggi di kawasan pertengahan dan hilir lembangan sungai yang disebabkan oleh aktiviti manusia. Aras kepekatan adalah bertambah untuk kedua-dua jenis nutrien di musim basah hasil daripada larut lesap dari daratan ke kolum air. Nisbah molar takorganik terlarut N:P (nitrat + ammonia: tak organik P) adalah sangat tinggi (72:1) berbanding nisbah Redfield (16:1) yang mencadangkan faktor penghad nutrien untuk pertumbuhan fitoplankton di sungai ini adalah P. Hasil daripada kajian ini boleh digunakan sebagai perbandingan dasar pemantauan seterusnya untuk lembangan sungai ini.
\end{abstract}

Kata kunci: air permukaan, nutrien, nisbah N:P, lembangan Sungai Besut 


\section{Suhaimi et al: NUTRIENT DISTRIBUTION IN THE BESUT RIVER BASIN, TERENGGANU, MALAYSIA (SOUTH CHINA SEA)}

\section{Introduction}

Nutrient input to surface water has increased dramatically in recent decades and anthropogenic activities are the major sources [1]. These anthropogenic sources include both domestic and industrial wastewater discharge, agricultural practices, mining and atmospheric deposition. Nitrogen $(\mathrm{N})$ - and phosphorus $(\mathrm{P})$-based nutrients are important for primary productivity and also the most threatening pollutants for most aquatic systems [2, 3]. Excessive levels of both nutrients in the surface water contribute to the deterioration of water quality through processes such as eutrophication, and hence contribute to hypoxic events $[4,5]$. Besides light, nutrients are the major factor controlling the growth of phytoplankton and most studies have shown that $\mathrm{N}$ and $\mathrm{P}$ are the limiting nutrients for marine and freshwater systems, respectively [6, 7].

The Besut River basin is situated on the east coast of Peninsular Malaysia. The Besut River is the largest river in the district of Besut, Terengganu, is approximately $40 \mathrm{~km}$ in length and flows from Besut to the mouth of the river at Kuala Besut and discharges into the southern part of the South China Sea. The Besut River basin comprises the Besut River and its main tributaries such as the Pelagat, Jertih, Tenang, Angga, Peda, La and Keruak Rivers. This area experiences a tropical climate and is strongly influenced by the Northeast (NE) monsoon from November to February and Southwest (SW) monsoon from March to September. The NE monsoon season brings heavy rains to this area and is known as the wet season, while the SW monsoon is referred to as the dry season [8]. The main anthropogenic activities in this basin are agriculture and residential. The residential areas are concentrated in three major towns, namely Jertih, Kampung Raja and Kuala Besut. There are no major industrial activities in this basin. This river basin is important since it provides water for irrigation as well as water supplies for the surrounding areas and also provides waste water dilution [9].

This study focused on the distribution of N-based nutrients (nitrate, ammonia, total dissolved N (TDN) and total particulate N (TPN)) and P-based nutrients (dissolved inorganic P (DIP), total dissolved P (TDP) and total particulate $\mathrm{P}$ (TPP)) during the dry and wet seasons. The concentration of chlorophyll-a (chl-a) as an indicator of phytoplankton biomass was also determined. The molar ratio of dissolved inorganic N:P was calculated in order to know the limiting nutrient in this basin.

\section{Materials and Methods}

Sampling was carried out during dry pre-monsoon (2/6/2002, 4/8/2002 and 26/10/2002) and wet monsoon (23/11/2002) periods at eight sampling stations (B1, B2, B3, B4, B5, B6, B7 and B8) as shown in Figure 1. All stations were located in the freshwater area. Only one sampling was performed during the wet monsoon period due to rough weather conditions which most of the stations were flooded and could not be accessed. Due to the water shallow $(<2 \mathrm{~m})$, water samples were only collected by hand-dipping the bottles beneath the water surface and stored in acid-washed polyethylene bottles. The samples were temporarily placed in an ice cooler and transported to the laboratory. At the laboratory, $500 \mathrm{~mL}$ samples were vacuum-filtered through $0.45 \mu \mathrm{m}$ cellulose membrane filters and the dissolved samples were stored frozen at $-20{ }^{\circ} \mathrm{C}$ until analysis. The dissolved and particulate forms of the nutrients were analysed based on the standard colourimetric method [10]. The chl-a was determined spectrophotometrically [11]. The data obtained were then tested by two-way analysis of variance (ANOVA) at the 95\% significance level to show differences between sampling dates and sampling stations. 


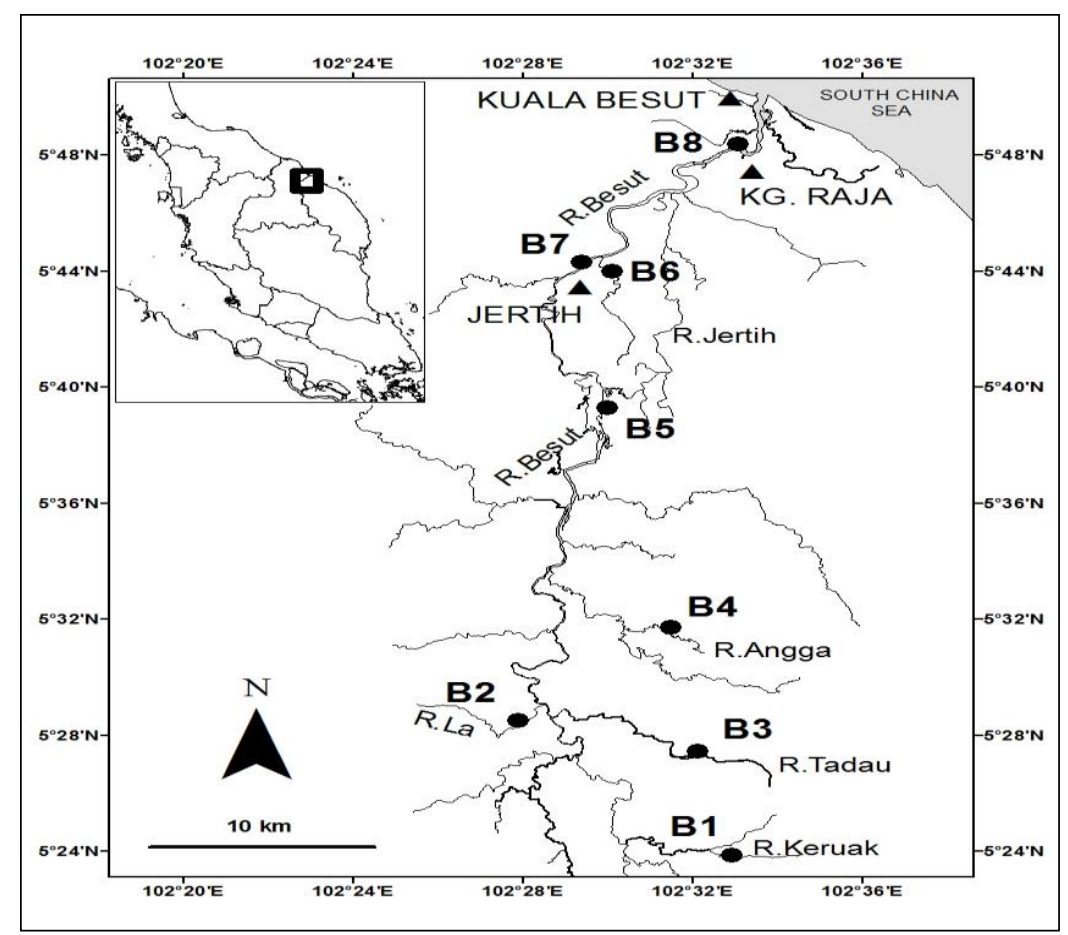

Figure 1. Location of sampling stations in the Besut River basin

\section{Nutrients and chl-a distribution}

\section{Results and Discussion}

Figures 2 and 3 show the distribution of $\mathrm{N}$ - and P-based nutrients in the Besut River basin. Based on the ANOVA test, in general all nutrients showed no significant difference ( $p>0.05)$ between sampling stations, but did show significantly differences $(\mathrm{p}<0.05)$ between sampling dates. Among the N-based nutrients, TDN recorded higher

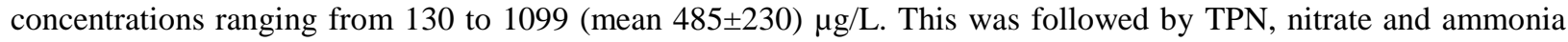

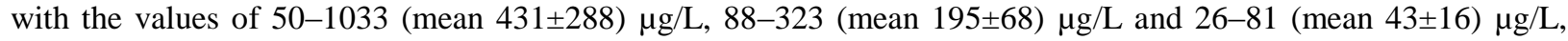
respectively. For the P-based nutrients, higher ranges of concentrations were observed for TPP: 2.28-19.32 (mean $8.35 \pm 4.32) \mu \mathrm{g} / \mathrm{L}$. The concentrations of TDP and DIP varied from 1.54 to 12.21 (mean $4.84 \pm 2.67$ ) $\mu \mathrm{g} / \mathrm{L}$ and from 0.28 to 7.28 (mean $2.30 \pm 1.83) \mu \mathrm{g} / \mathrm{L}$, respectively.
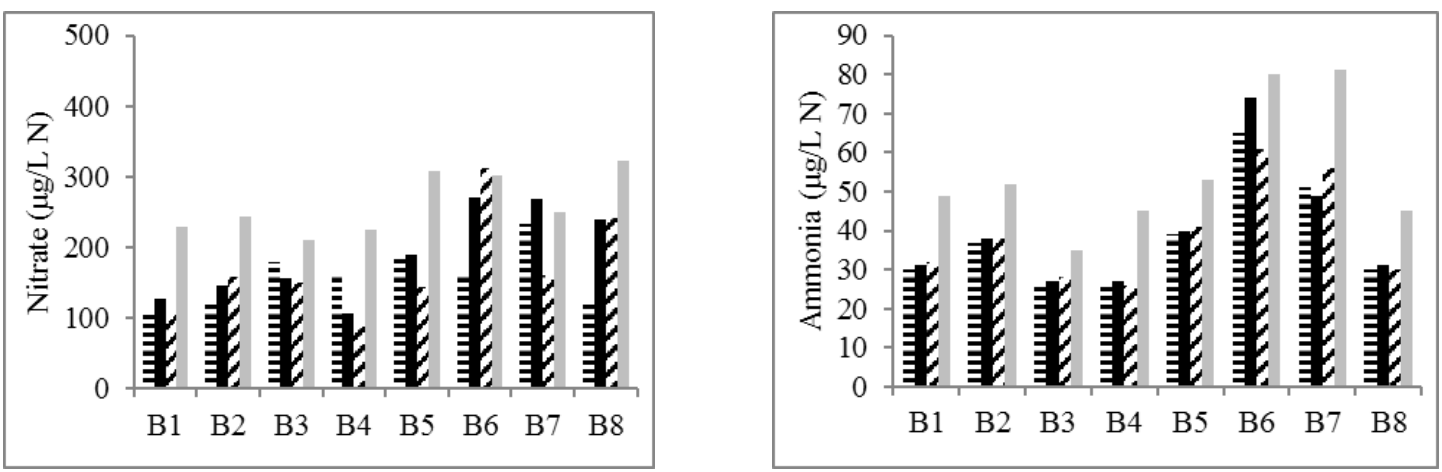

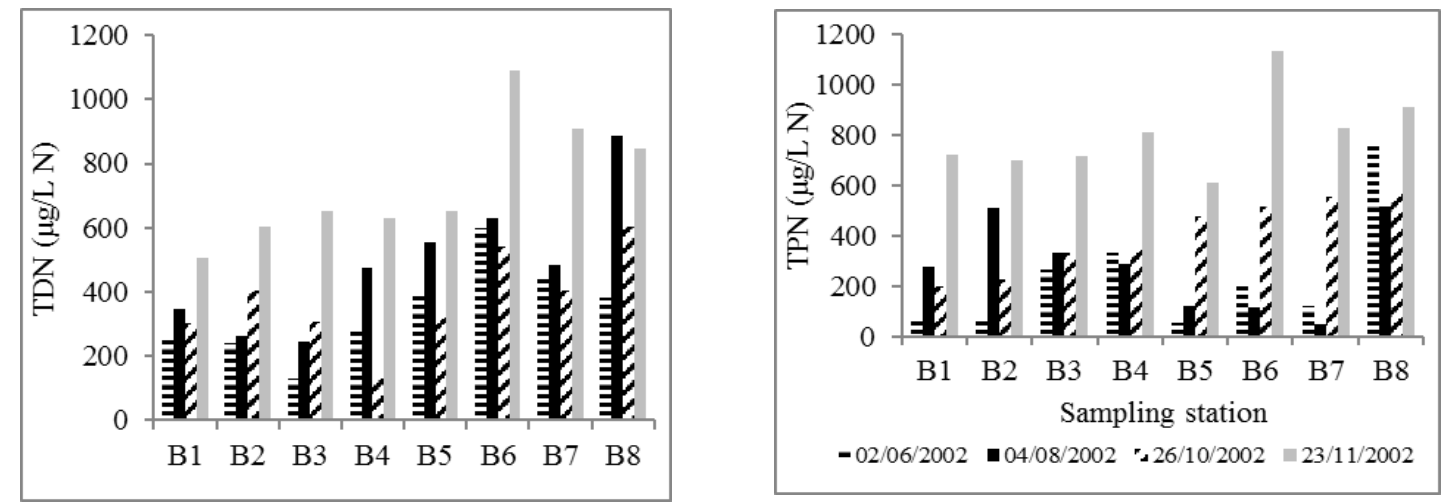

Figure 2. Variation of N-based nutrient concentrations in the Besut River basin
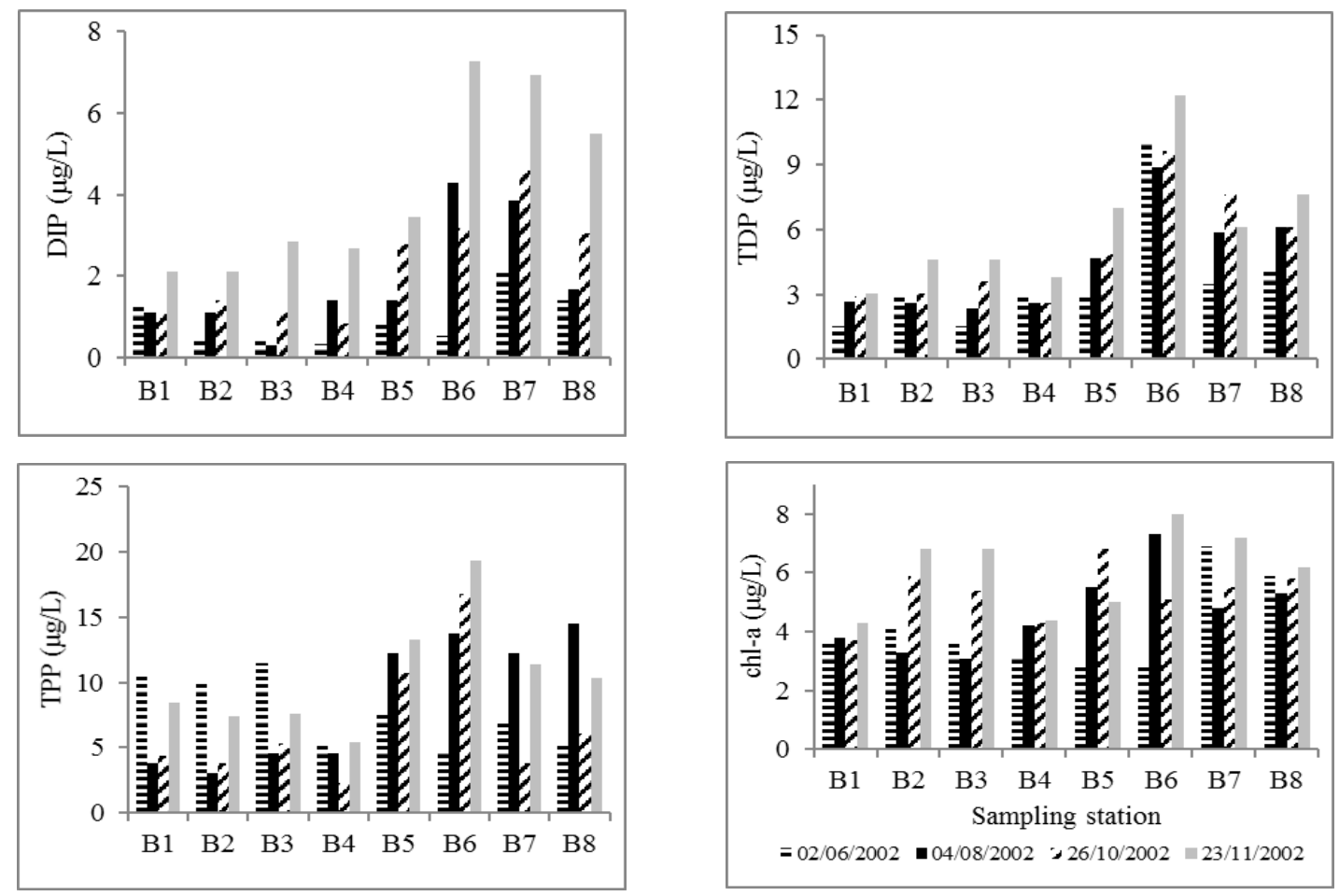

Figure 3. Variation of P-based nutrient concentrations in the Besut River basin

An increasing trend of nutrient concentrations was found going from the upstream to the downstream stations, especially at stations B6, B7 and B8 at which recorded among the highest concentrations. As mentioned earlier, the main activities in this river basin are agriculture and residential areas, which concentrated in the three towns Jertih, Kampung Raja and Kuala Besut. These towns are located in the middle and downstream areas of this river basin. It is believed that there is no proper waste management in these towns as most of the sewage effluent flows straight into the river. These effluent sources include domestic sewage and municipal waste water. Numerous studies have revealed domestic and municipal effluents as an important source of nutrients to river systems [12-14]. Run-off from agricultural activities can also contribute to enhanced nutrient contents through the diffusion process, especially when excessive fertilizers are used $[15,16]$. Even though agricultural activities (palm oil plantation) are practised at the upper reaches of this river, the nutrient concentrations here were relatively low compared to downstream stations which implies that agricultural activities have a minimal influence on nutrient concentrations in this river basin. 
In general, the nutrient distributions were high during the wet monsoon period compared to the dry pre-monsoon period. Many studies also recorded the same observation in their study area [17-19]. An observed increase in the nutrients measured during the wet monsoon period was associated with heavy rainfall that leads to peak river discharge and high terrestrial run-off. The run-off component from the land includes agricultural and municipal wastes from the surrounding area and is responsible for high concentrations of nutrients along the surface of the Besut River basin. Conversely, during the dry season period, lower nutrient concentrations were recorded. This is possibly due to little rainfall causing weakened river flow and diminished the flushing from upstream during the dry season, therefore the waste water drainage and nutrient inputs to the water column were also low.

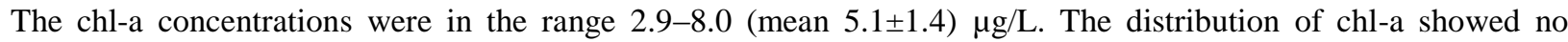
significant difference ( $p>0.05)$ between sampling stations, but again significant differences $(p<0.05)$ between sampling dates based on the ANOVA test. In general, higher chl-a concentrations were recorded at the middle and upstream stations which may be due to high nutrient input in these particular areas.

A comparison of data obtained from the present study has been made with selected previous data from river basins in Malaysia (Table 1). In general, the Besut River basin recorded lower concentrations of nutrients. This is probably due to the fact that there are no major anthropogenic activities within the basin; most activities are related to agriculture and residential areas. The Marang, Kemaman and Nerus River basins recorded relatively higher values of nutrients in Terengganu due to large scale agriculture and plantation activities in these areas. In addition, a few big towns are located in these three river basins such as Marang, Chukai and Kuala Terengganu. The Selangor River basin recorded higher concentrations for most of the nutrients which could be attributed to input from municipal waste, aquaculture farms and ex-mining ponds. As reported for the Bertam River, discharge of waste and use of fertilizers in farming areas were the main sources of nutrients. Sand mining in the river can also increase the nutrient concentrations as this activity could result in the resuspension of sediment, which could release a significant amount of nutrients attached to the sediment into the river water as observed in the Kelantan River.

Table 1. Comparison of nurients within selected area in Malaysia river basin

\begin{tabular}{|c|c|c|c|c|c|c|c|c|}
\hline \multirow{2}{*}{ River } & \multicolumn{4}{|c|}{ Nitrogen $(\mu \mathrm{g} / \mathrm{L} \mathbf{N})$} & \multicolumn{3}{|c|}{ Phosphorus ( $\mu \mathrm{g} / \mathrm{L} \mathrm{P})$} & \multirow{2}{*}{ Ref. } \\
\hline & Ammonia & Nitrate & TDN & TPN & DIP & TDP & TPP & \\
\hline Besut, Terengganu & $26-81$ & $88-323$ & $\begin{array}{l}130- \\
1,099\end{array}$ & $\begin{array}{l}50- \\
1,033\end{array}$ & $\begin{array}{l}0.28- \\
7.28\end{array}$ & $\begin{array}{l}1.54- \\
12.21\end{array}$ & $\begin{array}{l}2.28- \\
19.32\end{array}$ & $\begin{array}{l}\text { This } \\
\text { study }\end{array}$ \\
\hline Marang, Terengganu & $16-161$ & $65-426$ & - & - & $27-62$ & - & - & [12] \\
\hline Kemaman,Terengganu & - & $31-496$ & - & $\begin{array}{l}143- \\
1652\end{array}$ & $\begin{array}{l}1.28- \\
26.12\end{array}$ & - & $\begin{array}{l}4.89- \\
468.30\end{array}$ & [20] \\
\hline Nerus, Terengganu & $1-35$ & $174-743$ & - & - & $4-29$ & - & - & [21] \\
\hline Selangor, Selangor & $10-980$ & $50-4300$ & $\begin{array}{l}510- \\
13,400\end{array}$ & - & $1-123$ & $4-370$ & - & [22] \\
\hline Sarawak, Sarawak & $30-670$ & $30-140$ & - & - & $\begin{array}{l}30- \\
740\end{array}$ & - & - & [23] \\
\hline Kelantan, Kelantan & $260-410$ & $\begin{array}{l}13,300- \\
21,700\end{array}$ & & - & - & - & - & [24] \\
\hline Liwagu, Sabah & $50-300$ & $\begin{array}{l}700- \\
3,500\end{array}$ & - & - & $\begin{array}{l}60- \\
480\end{array}$ & - & - & [25] \\
\hline Merbok, Kedah & $10-3,410$ & $10-410$ & - & - & $\begin{array}{l}20- \\
160\end{array}$ & - & - & [26] \\
\hline Bertam, Pahang & $70-190$ & $\begin{array}{l}720- \\
3,410\end{array}$ & - & - & $\begin{array}{l}800- \\
1,350\end{array}$ & - & - & [27] \\
\hline
\end{tabular}

- = not analysed 


\section{N:P ratio}

The relationship between two parameters can be obtained via plot regressions of one parameter against another. This technique requires sufficient variability in the various parameters for the slope of the line to be determined. By using the whole data, the regressions between the concentrations of chl-a versus DIN (nitrate + ammonia) and chl-a versus DIP were determined as shown in Figure 4 (note that the concentrations of DIN and DIP have been changed from $\mu \mathrm{g} / \mathrm{L}$ to $\mu \mathrm{M})$. It appears that the chl-a concentrations of all samples were highly correlated with $\mathrm{DIN}\left(\mathrm{R}^{2}=0.31\right.$; $\mathrm{R}=0.56)$ and DIP $\left(\mathrm{R}^{2}=0.53 ; \mathrm{R}=0.73\right)$. This means that the distribution patterns of chl-a (as an indicator for phytoplankton) were influenced by the inorganic nutrients. This result is consistent with other studies and further supports the argument that inorganic nutrients are the major nutrients for phytoplankton growth [6, 28, 29].
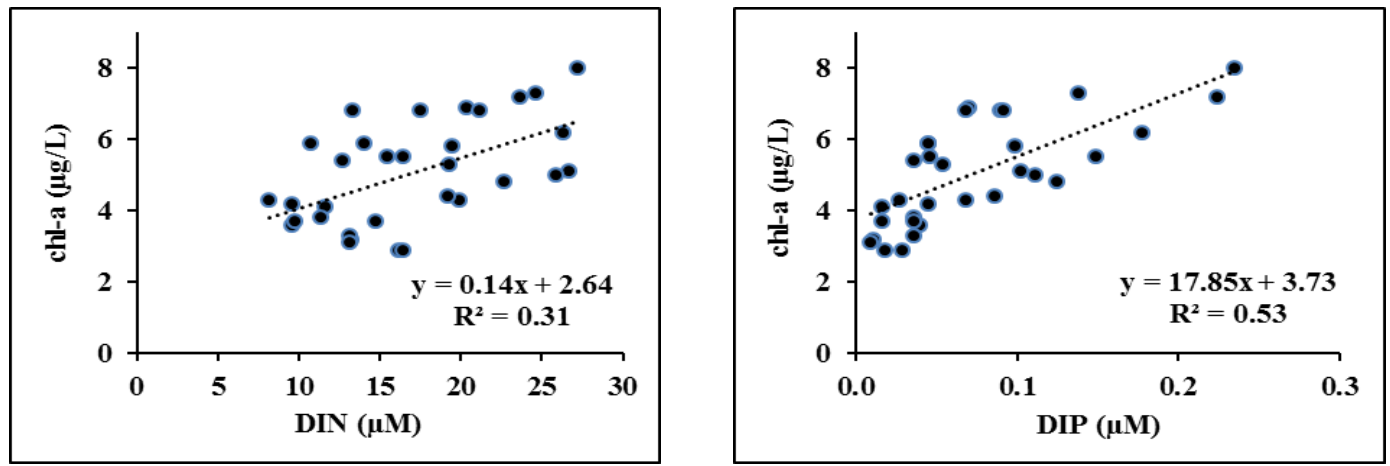

Figure 4. Molar concentrations of DIN and DIP versus chl-a

The regression graph of DIN versus DIP was plotted in order to determine the molar ratio of N:P in the Besut River basin (Figure 5). Although some studies have used the total concentrations of $\mathrm{N}$ and $\mathrm{P}$ in order to calculate the N:P molar ratio [16, 29], the inorganic forms of $\mathrm{N}$ - and P-based nutrients are the major nutrients used for phytoplankton growth $[28,29,31]$, hence DIN and DIP were used here. The slope of the graph indicated that the N:P mean molar ratios of all samples was about $72: 1\left(R^{2}=0.57 ; R=0.76\right)$. This value is much higher than the value proposed by Redfield ratio (16:1), which is probably due to high DIN input from agriculture and residential areas in the Besut River basin. The calculated N:P molar ratio showed that DIP is the limiting nutrient in the Besut River basin, i.e. the primary production of phytoplankton is controlled by the availability of DIP. Many studies of surface freshwater systems have also observed the same trends of P-limiting nutrients in their area such as Colorado Lakes, U.S [29], Setiu River, Malaysia [32], Lake Michigan, U.S. [33] and Lake Baringo, Kenya [34]. For the freshwater system, the main input of nutrients is from point and non-point sources which are mainly from agriculture, industrial and domestic wastes. In going from the terrestrial to the aquatic system (e.g. run-off from land), the movement of P is more limited compared to the $\mathrm{N}$ due to the process of $\mathrm{P}$ binding to the soils [7]. As a result, $\mathrm{N}$ is more likely to flow to the freshwater, making $\mathrm{P}$ relatively very low in concentration and more limiting than $\mathrm{N}$.

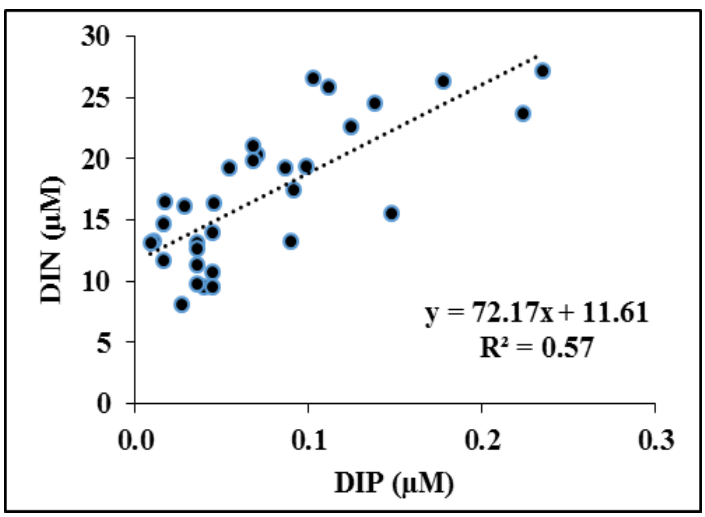

Figure 5. The molar ratio of DIN versus DIP 


\section{Conclusion}

The present study shows that nutrients in both dissolved and particulate forms were higher downstream compared to upstream of the Besut River basin. This situation revealed the influence of continuous input from domestic and municipal discharges from three major towns in the Besut River basin. The high concentrations of the nutrients observed during the wet monsoon period were possibly due to the run-off process from the land into the river. Comparisons with other study areas showed that nutrient concentrations in the Besut River basin were still low. Based on the calculated N:P molar ratio, the limiting nutrient in this study area was DIP. The results obtained were based on the short term sampling. It is suggested to prolong the sampling in order to get more data of nutrients input, their loading and model it. This further assessment should provide a better understanding of nutrients distribution and related process for future prediction and comparison study.

\section{Acknowledgements}

The authors appreciated the Department of Chemical Sciences, Universiti Malaysia Terengganu for the financial support. This work was partly supported by the Higher Institution Centre of Excellence (HICoE) research grant (Vote no. 66928) awarded to the Institute of Oceanography and Environment, Universiti Malaysia Terengganu. The assistance of Norsuria Yahaya and Siti Rahayu A. Rashid in the sampling and analysis is kindly acknowledged. We are grateful for the helpful comments on the manuscript from anonymous reviewer. Thanks to Dr. Rose Norman for assistance with proof reading of the manuscript.

\section{References}

1. Jickells, T. D., Andrews, J. E., Parkes, D. J., Suratman, S., Aziz, A. A. and Hee, Y. Y. (2014). Nutrient transport through estuaries: The importance of the estuarine geography. Estuarine, Coastal and Shelf Science, 150: 215-229.

2. Drolc, A., and Zagorc, K. J. (2008). Diffuse sources of nitrogen compounds in the Sava River basin, Slovenia. Desalination, 226(1-3): 256-261.

3. Gao, W., Howarth, R. W., Swaney, D. P., Hong, B., and Guo, H. C. (2015). Enhanced N input to Lake Dianchi basin from 1980 to 2010: drivers and consequences. Science of the Total Environment, 505: 376-384.

4. Ling, T. Y., Michelle, C. M., Nyanti, L., Norhadi, I. and Justin, J. J. E. (2010). Impacts of aquaculture and domestic wastewater on the water quality of Santubong River, Malaysia. Journal of Environmental Science and Engineering, 4 (4): 11-16.

5. Hee, Y. Y. and Suratman, S. (2016). Physico-chemical parameter profile during dry and wet seasons in southern South China Sea. Asian Journal of Chemistry, 28(10): 2146-2152.

6. Smith, V. H. (2003). Eutrophication of freshwater and coastal marine ecosystems. A global problem. Environmental Science and Pollution Research, 10(2): 126-139.

7. Statham, P. J. (2012). Nutrients in estuaries-an overview and the potential impacts of climate change. Science of the Total Environment, 434: 213-227.

8. Malaysia Meteorological Department, MMD (2008). Access from http://www.met.gov.my/english/ education/climate/climate01.html). Access online 15 May 2018.

9. Suratman, S., Hang, H. C., Shazili, N. A. M. and Mohd Tahir, N. (2009). A preliminary study of the distribution of selected trace metals in the Besut River basin, Terengganu, Malaysia. Bulletin of Environmental Contamination and Toxicology, 82: 16-19.

10. Grasshoff, K., Ehrhardt, M. and Kremling, K. (1983). Determination of nutrients. In: Methods of seawater analysis $2^{\text {nd }}$ edition. Florida: Verlag Chemie: pp. 419.

11. Parsons, T. R., Maita, T. and Lalli, C. M. (1984). Plant pigment. In: A manual of chemical and biological method for seawater analysis. Oxford: Pergamon Press: pp. 173.

12. Suratman, S. and Mohd Tahir, N. (2013). Kesan antropogenik terhadap kualiti air di lembangan Sungai Marang, perairan selatan Laut China Selatan. Sains Malaysiana, 42(6): 743-751.

13. Shiddamaiilayya, N. and Pratima, M. (2008). Impact of domestic sewage on freshwater body. Journal of Environmental Biology, 29(3): 303-308.

14. Badr, E. S. A. (2016). Spatio-temporal variability of dissolved organic nitrogen (DON), carbon (DOC), and nutrients in the Nile River, Egypt. Environmental Monitoring and Assessment, 188(10): 580. 
15. Kim, G., Chung, S. and Lee, C. (2007). Water quality of runoff from agricultural-forestry watersheds in the Guem River basin, Korea. Environmental Monitoring and Assessment, 134: 441-452.

16. Shen, Z-.L. and Liu, Q. (2009). Nutrients in th Changjiang River. Environmental Monitoring and Assessment, 153: 27-44.

17. Rahaman, S. M., Sarder, L., Rahaman, M., Ghosh, A., Biswas, S., Siraj, S. and Islam, S. (2013). Nutrient dynamics in the Sundarbans mangrove estuarine system of Bangladesh under different weather and tidal cycles. Ecological Processes, 2(1): 29.

18. Anand, S. S., Sardessai, S., Muthukumar, C., Mangalaa, K. R., Sundar, D., Parab, S. G. and Kumar, M. D. (2014). Intra and inter seasonal variability of nutrients in a tropical monsoonal estuary (Zuari, India). Continental Shelf Research, 82: 9-30.

19. Kawasaki, N., Nagao, N., Yusoff, F., Imai, A. and Kohzu, A. (2016). Seasonal changes of nutrient distributions along Selangor River, Malaysia. International Journal of Advances in Chemical Engineering and Biological Sciences, 3(1): 113-116.

20. Suratman, S, Hee, Y. Y. and Mohd Tahir, N. (2014). Nutrient status of the Kemaman River basin in the southern South China Sea (Malaysia). Asian Journal of Chemistry, 26(7): 2047-2052.

21. Mohd Tahir, N., Suratman, S., Jusoh, S. R., Yahaya, S. N., Mohd Yusoff, N. and Law A. T. (2005). Penentuan indeks kualiti air dan nutrien terlarut di Sungai Nerus, Terengganu. Malaysian Journal of Analytical Sciences, 9(1): 193-197.

22. Kawasaki, N., Kushari, M. R. M., Nagao, N., Yusoff, F., Imai, A. and Kohzu, A. (2016). Seasonal changes of nutrient distributions along Selangor River, Malaysia. International Journal of Advances in Chemical Enggering and Biological Sciences, 3(1): 113-116.

23. Heng, L. Y., Madhan, M., Sumok, P. and Chukong, L. N. (2007). Pemonitoran intensif beberapa nutrien dalam Sungai Sarawak di Kuching, Sarawak, Malaysia. Sains Malaysiana, 36(2): 133-137.

24. Yen, T. P. and Rohasliney, H. (2013). Status of water quality subject to sand mining in the Kelantan River, Kelantan. Tropical Life Sciences Research, 24(1): 19-34.

25. Cleophas, F., Isidore, F., Han, L. K. and Bidin, K. (2013). Water quality status of Liwagu River, Tambunan, Sabah, Malaysia. Journal of Tropical Biology and Conservation, 10: 67-73.

26. Fatema, K., Wan Maznah, W. O. and Mat Isa, M. (2014). Spatil and tmporal variation of physico-chemical parameters in the Merbok estuary, Kedah, Malaysia. Tropical Life Sciences Research, 25(2): 1-19.

27. Khalik, W. M. A. W. M., Abdullah, M. P., Padli, N. and Amerudin, N. A. (2013). Assessment on nutrient status in water and sediment quality of Bertam River, Cameron Highlands. International Journal of Chemical Sciences, 11(2): 709-720.

28. Jordan, M. M. and Joint, I. (1998). Seasonal variation in nitrate:phosphate ratios in the English Channel 19231987. Estuarine, Coastal and Shelf Science, 46: 157-164.

29. Morris, D. P. and Lewis, W. M. (1988). Phytoplankton nutrient limitation in Colorado mountain lakes. Freshwater Biology, 20: 315-327.

30. Tamminee, T. (1982). Effects of ammonium effluents on planktonic primary production and decomposition in a coastal brackish water environment 1 . Nutrient balance of the water body and effluent test. Netherland Journal of Sea Research, 16:455-464.

31. Luo, G., Bu, F., Xu, X., Cao, J. and Shu, W. (2011). Seasonal variations of dissolved inorganic nutrients transported to the Linjiang Bay of the Three Gorges Reservoir, China. Environmental Monitoring and Assessment, 173: 55-64.

32. Suhaimi, S., Mohd Tahir, N. and Suryati, S. (2004). Dissolved nutrients and chlorophyll a status of the Setiu River, Terengganu, Malaysia. Bulletin of Environmental Contamination and Toxicology, 73(6): 1094-1100.

33. Schelske, C. L. and Stoemer, E. F. (1972). Phosphorus, silica, and eutrophication of Lake Michigan. Pages 157-171. In: Nutrients and Eutrophication. G. E. Likens (editor) American Society Limnology Oceanography, Allen Press, Lawrence.

34. Okech, E.O., Kitaka, N., Oduor, S.O. and Verschuren, D. (2018). Tropic state and nutrient limitation in Lake Baringo, Kenya. African Journal of Aquatic Science, 43(2):169-173. 